\title{
Okra (Abelmoschus Esculentus) As Food Substitute to Increase Fiber and Protein Content of Fungal Fermented Food
}

\author{
OKRA (ABELMOSCHUS ESCULENTUS) SEBAGAI SUBSTITUSI PANGAN UNTUK \\ MENGINGKATKAN SERAT DAN KADAR PROTEIN PANGAN FERMENTASI JAMUR
}

\author{
Dian Yustika Rini1, ${ }^{*}$, Arif Sabta Aji1,2, Veriani Aprilia², Herni Dwi Herawati2, \\ Syuja Rafiqi Arifin ${ }^{2}$, Rosi Novita ${ }^{3}$ \\ ${ }_{1}^{1}$ Graduate School of Public Health Department, Alma Ata University, Yogyakarta, Indonesia. \\ ${ }^{2}$ Department of Nutrition, Faculty of Health Sciences, Alma Ata University, Yogyakarta, Indonesia. \\ 3 Department of Nutrition, Poltekkes Kemenkes Aceh, Aceh, Indonesia. \\ *Email corresponding author: 200800016@almaata.ac.id
}

\begin{abstract}
Fungal fermented foods, such as tempe, are nutritious, affordable, and a good source of protein. Nuggets are known as chicken based ultra-processed food. However, Tempe as raw materials are rarely processed. The combination of Tempe nuggets and additional Okra could improve the nutritional content such as protein and fiber. The current study aimed to investigate the correlation between additional of Okra in Tempe nuggets product and nutritional content, and sensory characteristics of fungal fermented food. Experimental design research was conducted from May to July 2019. Total of three treatments and three repetitions were carried out to develop this product including A1 (85\% Okra and 15\% Tempe flour), A2 (75\% Okra and 25\% Tempe flour) and A3 (65\% Okra and 35\% Tempe flour). Semi-trained panelists selected to perform sensory test. Protein and fiber of produce was assessed by kjeldahl method and soxhlet method. The results indicated that Okra substitution were significantly liking of the color, taste, and aroma of the product $(p<0.05)$, but not in texture indicator $(p=0.06)$. Protein content of the product increased significantly in A3 formulation. However, the fiber content had no significantly difference between Tempe and Okra substitution ( $p=0.38$ ). Okra has potential dietary food substitution to increase the protein of the fungal fermented food product. The combination formula of Tempe and Okra has significant impact on the level of preference in color, flavor, and aroma of the Tempe nugget product. Future researches are required to confirm this finding and contribute the development of Tempe nugget product.
\end{abstract}

Keywords: Fungal fermentation; Tempe, Nugget, Okra; Sensory Profile; Protein; Fiber.

\section{INTRODUCTION}

Processes that are expanding in the food sector produce more diverse processed products that are widely distributed in the market. Nuggets are one of the most popular processed foods among consumers in Indonesia especially among children [1]. The filler and basic ingredients used in the manufacture of nuggets determine the characteristics of the nuggets produced. Typically, the basic ingredients are chicken, fish, and shrimp; however, chicken contains more fat than Tempe. Fillers, on the other hand, can be replaced with other food ingredients to help the body get the nutrients it needs. According to the findings of the Total Diet Study's Individual Food Consumption Survey (SKMI), the population's consumption of vegetables and processed foods remains low [2]. 
According to the National Standardization Agency (SNI) (2012), Indonesia is the world's largest producer of soybean fermented food such as Tempe and Asia's largest soybean market [3]. Half of Indonesia's soybean consumption is used to produce Tempe, $40 \%$ tofu, and $10 \%$ in the form of other products (such as taco, soy sauce, etc.) [4]. The nutritional content of 100 grams of Tempe contains 20.8 grams of protein, 8.8 grams of fat, 13.5 grams of carbohydrates, 1.4 grams of fiber, 4 grams of iron [5]. Based on its nutritional content, Tempe is a good source of nutrition, especially protein, but there are some opinions that need to take it into account about Tempe as a food ingredient due to consider Tempe only for people with low social levels and low-class protein source as a food in Indonesia [6].

Okra is a vegetable plant in the Malvaceae family. This plant grows in many countries and is widely distributed from Africa to Asia, southern Europe, and America. Okra contains vitamin C, vitamin E, water, protein, fat, carbohydrates, fiber, iron, calcium, and magnesium which are known to have superior nutritional quality [7]. According to research Agustiana (2020) stated that the addition of Okra in food ingredients can increase the percentage of fiber content in the food [8]. Tempe nuggets are expected to increase the nutritional value including the fiber in Tempe which has a low value with adding Okra substitution in the Tempe nugget product. The substitution of the specific vegetables or fruits into a specific food could help to improve the daily fiber intake. However, people have low frequency in the consumption of vegetables and fruits. A study that conducted in Bantul with including 87 households and 261 subjects reported that $89.7 \%$ of respondents consume less vegetables and $81.6 \%$ of respondents consume less fruit. The results of the relationship between vegetable consumption and the level of fiber intake (p: 0.022; OR 9.25) and the results of the relationship between fruit consumption and the level of fiber intake (p: 0.000; OR 42) [9]. It is important to consume more fruits and vegetables to meet daily people's nutrition needs. However, not everyone likes vegetables, due to the unpleasant taste, texture, and smell. Therefore, the aim of this study was to examine nutrient contents of Tempe nuggets with the addition of Okra as vegetables alternative processed food as source of protein and fiber and to identify the sensory test and nutrition content including protein and fiber of Tempe nuggets product development.

\section{METHODS}

\section{Study design}

This study was experimental research with the experimental design used is Completely Randomized Design (CRD) with three different treatments. These group of treatments had combination of Okra and Tempe substitutions, namely treatment A1 (85\% Okra, 15\% Tempe), A2 (75\% Okra, 25\% Tempe), and A3 (65\% Okra, 35\% Tempe). The variables that will be examined in this study are chemical quality, namely analysis of protein content by Kjeldahl method, and analysis of fiber content by soxhlet [10]. As well as sensory testing by semi-trained panelists as many as 30 people covering taste, color, aroma, and texture on Tempe nuggets with Okra substitution. The research was carried out May to July 2019 at the Food Technology Laboratory, Department of Nutrition, Poltekkes, Ministry of Health, Aceh. Sensory test was performed at the Sensory Test Laboratory, and chemical analysis at the Analysis Laboratory of Nutrition Science and Feed Technology Department of Animal Husbandry, Faculty of Agriculture UNSYIAH. All the participants were given an inform consent prior to perform sensory test. Only participants who agreed to become panelist can participate in this study. 


\section{Stages of making Tempe nuggets}

The ingredients used in making nuggets are Tempe, Okra vegetables, wheat flour, and seasonings such as garlic, shallots, pepper, sugar, salt. The ingredients for made nuggets are bought in traditional markets. The materials and tools used for the sensory test were Okra substituted Tempe nuggets, mineral water, sensory test forms, and informed consent forms. This process of Tempe nugget production was modified from Runtuweni (2011) [11]. This study conducted a preliminary study to determine the concentration of Okra substitution in tempe nuggets. This research was conducted with five treatments which were treatment A1 (85\% Okra and 15\% Tempe), treatment A2 (75\% Okra and 25\% Tempe), treatment A3 (65\% Okra and 35\% Tempe), treatment A4 (55\% Okra and Tempe). 45\% Tempe), and treatment A5 (45\% Okra and 55\% Tempe). The preliminary study was conducted by semi-trained panelists, so that three preferred treatments were selected including A1 (85\% Okra and 15\% Tempe), treatment A2 (75\% Okra and 25\% Tempe), and treatment A3 (65\% Okra and 35\% Tempe). The initial stage of made nuggets is to prepare all the ingredients needed according to a standard recipe. This research uses 3 stages of processing, the first stage is made Tempe puree, the second stage is made Okra puree, and the last stage is mixing all the purees with the addition of flour and other spices. steamed for 20 minutes then the dough is coated with breadcrumbs, and put in the refrigerator before frying.

\section{Statistical analysis}

Data processing and analysis was carried out using ANOVA (Analysis of Variance) to see whether there was a significant difference between treatments. Then, continued with Duncan's test if the results showed a significant difference ( $p$-value <0.05) between the treatments carried out. All data were analyzed by Statistical Program for Social Science (SPSS) version 23 [12].

\section{RESULTS}

\section{Sensory test of Tempe nugget}

Tempe nuggets with Okra substitution gave various results on sensory test. Table 1 describes the results of data analysis from the ANOVA statistical test. The results of the analysis showed that there was a significant difference between the treatment samples in terms of taste, color, and aroma. Then, data was tested by Duncan's test statistical analysis. The results of ANOVA statistical analysis on texture showed no significant difference $(p=0.06)$.

Duncan's test is a follow-up test of the ANOVA statistical test on samples that show a significant difference. The results of Duncan's test on taste with treatment A1 (85\% Okra and 15\% Tempe) were not favored by the panelists, because the Okra vegetable content was more so that the resulting taste was dominant with the unpleasant taste of vegetables. The results of Tempe nuggets on the color of the panelists preferred treatment A3 (65\% Okra and 35\% Tempe), this was because the Tempe content was more than treatment A1 and treatment A2. The aroma of Tempe nuggets obtained the most favorable results in treatment A3 (65\% Okra and 35\% Tempe), caused by the addition of $35 \%$ tempe, so that it produces a delicious tempe nugget aroma.

Table 1. Result of Sensory Test

$\begin{array}{llll}\text { Treatment A1 } & \text { Treatment A2 } & \text { Treatment A3 } & \text { P-Value }\end{array}$




\begin{tabular}{|c|c|c|c|c|c|c|c|}
\hline \multirow[t]{2}{*}{$\begin{array}{c}\text { Sensory } \\
\text { Variables }\end{array}$} & \multicolumn{2}{|c|}{$\begin{array}{c}\text { (Okra 85\%, } \\
\text { Tempe 15\%) }\end{array}$} & \multicolumn{2}{|c|}{$\begin{array}{c}\text { (Okra } 75 \% \text {, } \\
\text { Tempe 25\%) }\end{array}$} & \multicolumn{2}{|c|}{$\begin{array}{c}\text { (Okra 65\%, } \\
\text { Tempe 35\%) }\end{array}$} & \\
\hline & Mean & SD & Mean & SD & Mean & SD & \\
\hline Taste & 2.82 & 0.68 & 3.22 & 0.83 & 3.65 & 0.68 & $<0.001$ \\
\hline Color & 3.28 & 0.68 & 3.35 & 0.75 & 3.82 & 0.71 & 0.016 \\
\hline Aroma & 3.34 & 0.59 & 3.47 & 0.51 & 3.74 & 0.70 & 0.045 \\
\hline Texture & 3.38 & 0.64 & 3.38 & 0.56 & 3.74 & 0.67 & 0.061 \\
\hline \multicolumn{8}{|c|}{ Duncan Test } \\
\hline Taste & \multicolumn{2}{|c|}{$2.82^{\mathrm{a}}$} & \multicolumn{2}{|c|}{$3.22^{\mathrm{b}}$} & \multicolumn{3}{|c|}{$3.65^{b}$} \\
\hline Color & \multicolumn{2}{|c|}{$3.28^{a}$} & \multicolumn{2}{|c|}{$3.35^{\mathrm{a}}$} & \multicolumn{3}{|c|}{$3.82^{b}$} \\
\hline Aroma & \multicolumn{2}{|c|}{$3.34^{\mathrm{a}}$} & \multicolumn{2}{|c|}{$3.47 \mathrm{ab}$} & \multicolumn{3}{|c|}{$3.74 \mathrm{~b}$} \\
\hline
\end{tabular}

Notes: $(a, b)$ the numbers followed by the same letter show no significant difference at the 0.05 level on different lines.

\section{Protein and fiber assessment of the Tempe nugget}

Table 2 describes the results of data analysis from the ANOVA statistical test. The results of the analysis showed that there was a significant difference between the treatment samples in terms of the protein content test. Then the data was tested by statistical analysis of Duncan's test. The results of the ANOVA statistical analysis on fiber content did not show a significant difference $(\mathrm{p}=0.06)$. Duncan test results showed the highest protein content in treatment A3 (65\% Okra and 35 Tempe), this was due to the addition of more tempe than treatment A1 (85\% Okra and 15\% Tempe) and treatment A2 (75\% Okra and 25\% Tempe).

Table 2. Protein and fiber content of the product

\begin{tabular}{|c|c|c|c|c|c|c|c|}
\hline \multirow[t]{2}{*}{$\begin{array}{l}\text { Nutrient } \\
\text { Contents }\end{array}$} & \multicolumn{2}{|c|}{$\begin{array}{c}\text { A1 } \\
\text { (Okra 85\%, } \\
\text { Tempe 15\%) }\end{array}$} & \multicolumn{2}{|c|}{$\begin{array}{c}\text { A2 } \\
\text { (Okra 75\%, } \\
\text { Tempe 25\%) }\end{array}$} & \multicolumn{2}{|c|}{$\begin{array}{c}\text { A3 } \\
\text { (Okra 65\%, } \\
\text { Tempe 35\%) }\end{array}$} & \multirow[t]{2}{*}{ P-Value } \\
\hline & Mean & SD & Mean & SD & Mean & SD & \\
\hline Protein, $\mathrm{g}$ & 6.35 & 0.19 & 6.74 & 0.57 & 7.71 & 0.26 & 0.01 \\
\hline Fiber, $\mathrm{g}$ & 2.44 & 0.13 & 3.11 & 0.87 & 2.58 & 0.43 & 0.38 \\
\hline \multicolumn{8}{|c|}{ Duncan Test } \\
\hline Protein, $g$ & \multicolumn{2}{|c|}{$6.35^{\mathrm{a}}$} & \multicolumn{2}{|c|}{$6.74^{\mathrm{a}}$} & & $7.71^{\mathrm{b}}$ & \\
\hline
\end{tabular}

Notes: $(a, b)$ the numbers followed by the same letter show no significant difference at the 0.05 level on different lines.

\section{DISCUSSION}

Taste is a response to chemical stimuli by human organs, namely the tongue as a taste bud [13]. The taste of the product has a very important role in determining the level of panelist acceptance and the quality or quality of a product. So that the taste can influence the panelists to try the product [14]. Tempe nuggets with Okra substitution in treatment A1 (85\% Okra and 15\% Tempe) produced a more dominant taste of the unpleasant vegetable taste. Treatment A2 (75\% Okra and 25\% Tempe) produced the bitter taste of Tempe, and treatment A3 (65\% Okra and 35\% Tempe) had a more dominant Tempe taste.

The difference in taste of the three nuggets was caused by the difference in the amount of Tempe and Okra formulations that were included in each treatment. Nuggets with the addition of $25 \%$ and $35 \%$ were more accepted by the panelists than nuggets with 15\% Tempe. In treatment A1 (85\% Okra and 15\% Tempe) the Okra content was higher 
than Tempe, making the taste of nuggets more dominant, typical of vegetables. The number of vegetables can affect the taste of nuggets, so that the number of vegetables is large, the taste of Tempe is covered [15]. So that the panelists prefer treatment A3 (65\% Okra and 35\% Tempe) which contains more Tempe.

Color is the first thing or sensory thing that is seen which also determines the acceptability of the product. If the appearance is less attractive then it is usually less liked by consumers even though the product has a good taste and high nutritional value [14]. The color difference is caused by the different ingredients in each nugget treatment. In terms of color, the panelists preferred treatment A3 (65\% Okra and 35\% Tempe) compared to treatment A1 (85\% Okra and 15\% Tempe), A2 (75\% Okra, 25\% Tempe). This is presumably because the Tempe content in treatment A3 (65\% Okra and 35\% Tempe) was higher than treatment A1 (85\% Okra and 15\% Tempe) and A2 (75\% Okra, $25 \%$ Tempe). So that the color combination of dark green vegetables is more covered with the color of Tempe. The color of a product is influenced by the materials used, as well as the heating process that gives color pigments [16]. Tempe is white in color due to the growth of the mycelia of molds which glue the soybean seeds together to form a solid texture. The degradation of soybean components in fermentation makes Tempe have a distinctive taste and aroma.

Tempe is a fermented soybean product that has compounds that cause off-flavor (flavours and aromas in processed soybean products) derived from soybeans. One of the deviations of the aroma is the unpleasant smell. The unpleasant odor is caused by the action of the lipoxygenase enzyme present in soybean seeds. The enzyme reacts with fat and produces an organic compound, namely ethyl-phenyl-ketone. The aroma is formed during the frying process, in this process a milard reaction occurs which will form the flavor components. Carmen (2003) states that the aroma of frying products is obtained from the aroma of cooking oil (unsaturated fatty acids) and the aroma formed due to the Maillard reaction (reaction of reducing sugars with peptides) [17].

Texture is the physical state of a food ingredient that appears to be known by touching the product, usually using the fingertips so that the texture of a food ingredient can be known [14]. Based on the results of statistical tests, it was found that the F-count value was 2.869 and the p-value was 0.061 , so it could be concluded that the Tempe and Okra nuggets had no significant effect. Because it was known that there was no difference, it was not continued with Duncan's test. According to Bambang Kartika (1988) Texture is a pressure sensation that is obtained with the mouth and is felt when bitten, chewed, swallowed or touched with a finger [18]. The response from the panelists with the texture of the nugget is a bit soft and not hard. The texture of the nugget according to SNI 01-6683-2002 is chewy and dense [19]. The absence of a difference can occur because the nuggets come from the same basic ingredient, namely Tempe, where Tempe itself has a rather dense texture so that the overall texture of Tempe nuggets is almost the same [20].

The protein content of nuggets obtained in this study was not in accordance with the SNI for nuggets, where the SNI for nuggets was $12 \%$. This may be due to the lack of composition of ingredients (both main ingredients and auxiliary ingredients) used in making these Tempe and Okra nuggets. Apriyantono, et al (1989) stated that, in the cooking or heating process, the protein content of the product increased, due to the release of water molecules by protein caused by a decrease in product weight [21]. 
Decreased water content will cause the protein content in the material to increase. The use of heat in food processing can reduce the percentage of water content which causes the percentage of protein content to increase. The drier the material, the higher the protein content. Based on the RDA table, it is known that the protein requirement for children aged 6-12 years is 50 grams and adults aged $>15$ years is 60 grams. The results of the protein content test of Tempe and Okra nuggets in treatment A3 $65 \%$ Okra and $35 \%$ Tempe) contributed $15.42 \%$ protein adequacy for children aged $6-12$ years, and $12.85 \%$ for adults aged $>15$ years based on the RDA and standards. vegetable side dishes need is $50 \mathrm{gr}$.

According to National Food and Drug Agency (2016), a food ingredient can be said to be a source of fiber if it has a fiber content of at least $3 \mathrm{~g} / 100 \mathrm{~g}$ of material. So that green Okra vegetables can be said to be a source of fiber [22]. Meanwhile, according to the Recommended Dietary Allowances (2013) consume fiber as much as 25-35gr/day [23]. Tempe and Okra nuggets produce $2-4 \mathrm{~g} / 100 \mathrm{~g}$ nuggets, so to meet daily fiber one must consume 10-15 pieces of Tempe and Okra nuggets. According with a study Risti D (2017) that also added 5\% glucomannan from porang (Amorphophallus oncophyllus) which is a source of fiber, but was not able to increase fiber content in nuggets [24]. The research from Marlina et al (2016) reported that the appearance of getuk with tolo bean substitution has a significant effect on fiber content, that it can be a high-fiber food [25].

\section{CONCLUSION}

This study found that there was no significant difference in the sensory test results of Tempe nuggets with texture acceptance because basically the texture of the nuggets was chewy and dense. There are significant differences in the acceptability of taste, aroma and color. This is because the more Okra is added, the more dominant the vegetable taste will be, different from the aroma and color, the more Tempe is added, the more attractive and savorier the resulting color will be. The results of chemical analysis showed that there was a significant difference in protein analysis and no significant difference in fiber analysis, because Okra vegetables are water soluble fiber, so that during processing the fiber content produced is less and does not meet the adequacy of fiber in a day. So, it is necessary to further research on Okra and fiber analysis, as well as consider the factors causing it.

\section{ACKNOWLEDGEMENTS}

The authors thank the research team for their help and cooperation during the research. Thank you to the Graduate School of Public Health Department, Alma Ata University, and Mrs. Rosi Novita from Poltekkes, Ministry of Health, Aceh, for their guidance. We appreciate all the hard work of the research team, panelists, and laboratory assistants who have helped.

\section{REFERENCES}

1. Kurniasari Y, Asrullah M, Aji AS. (2021). Millennial Perspective on Improving Sustainable Food Security. 1st ed. Yogyakarta: Alma Ata University Press.

2. Agency for Health Research and Development. (2014). Survey of individual food consumption in Indonesia's total diet survey book 2014. Jakarta: National report. 
3. National Standarization Agency. (2012). Tempe: Indonesia's gift to the world. PUSIDO. Jakarta. p. 1-15

4. National Standardization Agency. (2012). Tempe: Indonesia's Present for the World. Jakarta.

5. Indonesian Ministry of Health. DKBM (List of Food Ingredients Composition). (2000). Indonesian Ministry of Health. Jakarta.

6. Ahnan-Winarno AD, Cordeiro L, Winarno FG, Gibbons J, Xiao H. (2021). Tempe: A semicentennial review on its health benefits, fermentation, safety, processing, sustainability, and affordability. Comprehensive Reviews in Food Science and Food Safety. Vol. 20(2):1717-67. https://onlinelibrary.wiley.com/doi/abs/10.1111/1541-4337.12710

7. Kumar, D. S., Tony, D. E., Kumar, A. P., Kumar, K. A, Srinivasa Rao, D. B., dan Nadendla, R. (2013). A review on: abelmoschus esculentus (okra). Int. Res J Pharm. App Sci. Vol. 3(4):129-132

8. Agustiana. (2020). Sensory and Dietary Fiber Content of Wet Noodles with Addition of Green Okra Flour (Abelmuschus Esculentum L.). Yogyakarta.

9. Ridwan INN, Paratmanitya Y, Kurniasari Y. (2019). The Relationship of Vegetable and Fruit Consumption with Household Fiber Intake Level in Bantul District [Internet] [other]. [Yogyakarta]: Universitas Alma Ata Yogyakarta; 2019 [cited 2021 Nov 24]. Available from: http://elibrary.almaata.ac.id

10. Association of Official Analytical Chemist [AOAC]. (2005). Official Methods of Analysis (18 Edn). Association of Official Analytical Chemist Inc. Mayland

11. Runtuweni, Heniy. (2011). Recipe of Chinese food halal. Ida Ayu M \& Anna Maria F, editors. Kawan Pustaka. Jakarta

12. Gogoi P. (2020). Application of SPSS Programme in the Field of Social Science Research. Int J Recent Technol Eng. Vol. 8(5):2424-7

13. Rahayu, W. P., Nurosiyah, S. \& Widyanto, R. Evaluasi Sensori. 2 Red. (2019). Banten; Universitas Terbuka

14. Asy'ari., Jana Sidin. (2019). Sensory Test of Sago Plate with Addition of Skipjack Meat (Kotsuwonus Pelamis) and Flavoring. Vol. 14:1

15. Evanuraini, H. (2010). Quality Chicken nuggets with the addition of egg white. Universitas Brawijaya

16. Kasih, D. R. K. \& Purwidiani, N. (2019). Effect of Proportion of Corn Flour and Red Bean Flour on Sensory Properties and Nutritional Content of Steamed Brownies. Journal Cullinary; Vol. 8(2), p. 371-379.

17. Carmen, W. (2003). Nixtamalization, a Mesoamerican technology to process maize at small-scale with great potential for improving the nutritional quality of maize based foods. UNAM. Mexico

18. Kartika, K., Bambang, P., H, Hastuti dan Supartono. (1988). Food Sensory Test Guidelines. Yogyakarta: Universitas Gajah Mada

19. SNI. (2015). Soybean Tempe. Jakarta: National Standarization Agency SNI 3144: p:12

20. Ayu R.N, Fitri K. S, Kartika P. (2020). Tempe nugget with red bean flour substitution as iron rich food. Ponorogo

21. Apriyantono, dkk. (1992). Food Analysis. PAU Food and Nutrition. Bogor

22. National Food and Drug Agency, B. P. (2016). Decree of the Head of the Indonesian Food and Drug Supervisory Agency Number: HK.03.1.23.11.11.09909 concerning Supervision of Claims on Processed Food Labels and Advertisements. Jakarta: BPOM RI

23. Recommended Dietary Allowances. (2013). Nutrient Sufficiency Figures for Energy, Protein, Fat, Minerals and Vitamins Recommended for the Indonesian Nation. 
Attachment to Regulation of the Minister of Health of the Republic of Indonesia Number 75 of 2013

24. Risti. D.U, Variani A, Fatma Z N. (2017). Physical properties, fiber content, and acceptability of nuggets with the use of glucomannan from porang (Amorphophallus oncophyllus) for chicken meat substitution. Indonesian journal of nutrition and dietetics. Yogyakarta: Alma Ata University. Vol. 5(1):9-16. DOI : http://dx.doi.org/10.21927/ijnd.2017.5(1).9-16.

25. Marlina F, Dwi R. N, Elza I, Waluyo. (2016). Product development of getuk kacang tolo as alternative high fiber snack food. Indonesian journal of nutrition and dietetics. Vol.4(2):71-80. DOI: http://dx.doi.org/10.21927/ijnd.2016.4(2).71-80. 